\title{
Growth, Mortality, and Exploitation Rate of Penaeus merguensis in the North Coast of Central Java, Indonesia
}

\author{
Suradi Wijaya Saputra*, Anhar Sholichin and Wiwiet Teguh Taufani \\ Aquatic Resource Department, Faculty of Fisheries and Marine Science, \\ Diponegoro University, Jl. Prof Soedarto SH, Semarang, 50275 Indonesia \\ Email: suradiwsaputra@yahoo.co.id
}

\begin{abstract}
One of the most-caught shrimp in north coast of Central Java is Penaeus merguiensis. However, little is known on the population biology of the organisms. This study was aimed to investigate length-weight relationship, growth, length at first capture ( $\left.L_{c 50}\right)$, mortality rate, and exploitation rate of $P$. merguiensis in Western part of Central Java's northern coastal waters. The study was conducted from May 2016 to July 2017 using survey method. Samples were taken for 15 times (month) from 9 coastal fishing ports. The result shows that the relationship of the carapace length and weight is negative allometry. The growth parameters of $C L_{\infty}$ and $\mathrm{K}$ were $52.5 \mathrm{~mm}$ and 1.3 $y^{-1}$ (male) and $57.25 \mathrm{~mm}$ and $1.2 y^{-1}$ (female). Total mortality rate $(Z)$, natural mortality rate (M), and fishing mortality rate $(F)$ were $4.51 y^{-1}, 1.86 y^{-1}$ and $2.65 y^{-1}$ (male), and $5.36 y^{-1}, 1.72 y^{-1}$, and $3.64 y^{-1}$ (female), respectively. The exploitation rate $(E)$ of male banana shrimp was 0.59 , and for female shrimp was 0.68 . The result shows that the exploitation level has exceeded the optimum level (E>0.5). Recruitment of $P$. merguiensis may occur the whole year, but it peaks were in March and August (male), April and August (female). Carapace length of first captured $\left(C L_{c 50}\right)$ was $20.63 \mathrm{~mm}$ (male) and $18.28 \mathrm{~mm}$ (female). It means that the sized of captured $P$. merguiensis is less than the size of first mature $\left(C L_{m 50}\right)$ or growth overfishing and as a result, disrupting the availability of adult shrimp. The condition occurs due to the size of cod-end mesh measured $0.75 i n c$.
\end{abstract}

Keywords: natural population, exploitation, white shrimp, banana shrimp

\section{Introduction}

North coastal waters of Central Java are a part of Java Sea and included in Indonesia Fisheries Management Area (FMA) 712. The waters are potential for shrimp resources and therefore, a highexploited fisheries area. National Stock Assessment Commission published a study that, in 2016, the utilization level of Penaeid shrimp in this area has reached $121 \%$ of its sustainable potential. Penaeus merguiensis or white shrimp of banana shrimp is the most-caught valuable species in western part of northern coastal waters of Central Java.

Research on the length-weight relationship, growth, mortality rate, and exploitation rate is important as the basis of shrimp management. Several studies conducted on $P$. merguiensis related to the research topic are among others Tirtadanu and Ernawati (2016); Kembaren and Suman (2013); Nurdin and Kembaren (2015); Saputra and Subiyanto (2007); Siregar et al. (2014); Mane and Deshmukh (2011).

$P$. merguiensis spawn at the bottom of the water, between inshore and offshore. The shrimp is hatched as nauplii and growing as zoea, which is planktonic and carried away by current to the waters around the beach or estuary. It arrives in coastal waters in post larvae phase then grows into the juvenile and young shrimp. The shrimp will migrate to the sea to become adult shrimp and spawn (Bauer, 2011; Sheaveset et al. 2012). Shrimp caught in estuaries and coastal waters are the main issue of fisheries in many areas because the target of shrimp catch is post-larva, juvenile, and young shrimp. The gears used to catch were mini trawl, danish seine, arad, dogol, and sodo, which has a low level of selectivity. Although the gears have been prohibited based on the Regulation of Ministry of Marine Affairs and Fisheries No. 2/2015 and No. $71 / 2016$, yet the regulations have not effectively implemented. This study was aimed to analyze length-weight relationship, growth, mortality rate, and exploitation rate of $P$. merguiensis.

\section{Materials and Methods}

Samplings were carried out for 15 (fifteen) times (months), from May 2016 to July 2017 in northern coastal waters of Brebes to Kendal regency 


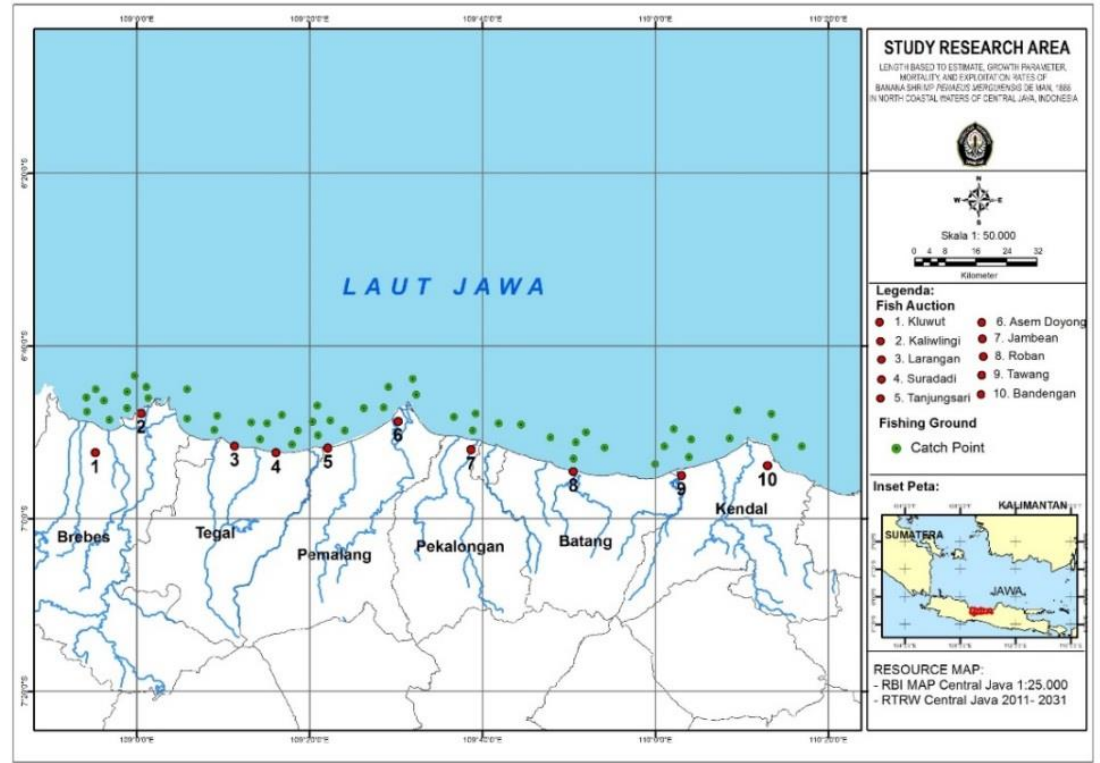

Figure 1. Research Map in the northern coastal waters of western Central Java, Indonesia

based on Saputra (2018). See Figure 1. Sample of shrimps were taken from the catch using Danish seine, in following fish landing bases (Coastal Fishing Port/CFP) i.e. Kaliwlingi and Kluwud (Brebes regency); Larangan and Suradadi (Tegal regency); Asemdoyong and Tanjungsari (Pemalang regency); East Roban (Batang regency); Bandengan and Tawang (Kendal regency). Systematic sampling method was used to determine the sample fishing vessels. The number of sample fishing vessel units was adjusted to the number of boats landing on a daily basis.

\section{Data measurement}

Data measurement and data recording were based on Saputra (2018), including sex, carapace length $(\mathrm{mm})$, total length $(\mathrm{mm})$, body weight $(\mathrm{g})$, and maturity level of the gonad of the shrimps. Total length and carapace length were measured by using a caliper with $0.1 \mathrm{~mm}$ accuracy, from the tip of the carapace (eye base) to the back of the rear carapace. Shrimp weight was measured using an electric scale, with $0.05 \mathrm{~g}$ precision. Shrimp sex was identified by observing the ventral part of the shrimp (in pleopod and periopod). Shrimps maturity level of gonads was identified morphologically by observing the color, shape, and size of the gonads, with the help of loops based on Motoh (1981), Croccos and Kerr (1983).

\section{Data analysis}

Length-weight relationships were determined according to Sparre and Venema (1999). The linear equation is $\log W=\log a+b \log C L$. The growth parameters $L_{\infty}$, and $K$ were estimated using Elefan software that is available in Fisat II program. The age at which the organism has mean length zero (to) was estimated by Pauly's formula, that is $\log \left(-t_{0}\right)=$ $0.392-0.275 \log L_{\infty}-1.038 \log \mathrm{K}$. The total mortality (Z) was estimated by means of the catch curve based on catch converted into length (Pauly, 1984). Natural mortality rate $(\mathrm{M})$ was estimated based on Pauly's empirical equation, that is Log $\mathrm{M}=-0.0066$ 0.279 Log $L_{\infty}+$ 0.6543. Log $K+0.4634$ Log $\mathrm{T}$. Recruitment pattern was analyzed using FiSAT II.

\section{Result and Discussion}

\section{Structure of shrimp size}

The size structure of male $P$. merguiensis shrimp during 15-month sampling is presented in Figure 2. The catch was typically dominated by one cohort. In May 2016, the carapace length was $22.5 \mathrm{~mm}$, then replaced by shrimp having the length at $25 \mathrm{~mm}$ in June, and changed to $27.5 \mathrm{~mm}$ in July. In August, the module returned to carapace length $22.5 \mathrm{~mm}$, then grew to $25 \mathrm{~mm}$ in the following month. In November, the size of carapace was $20 \mathrm{~mm}$, then grew to $22.5 \mathrm{~mm}$ in the following month.

Based on the data, it can be concluded that the recruit of $P$. merguiensis was $20-22.5 \mathrm{~mm}$. Based on its weight, the catch was dominated by 3-gram shrimp (estimated weight: $2-4 g$ ) as much as $41.3 \%$, and followed by $5 \mathrm{~g}$ shrimp as much as $25.5 \%$ (Figure 3.). The result shows that the size of caught shrimp was too small. 


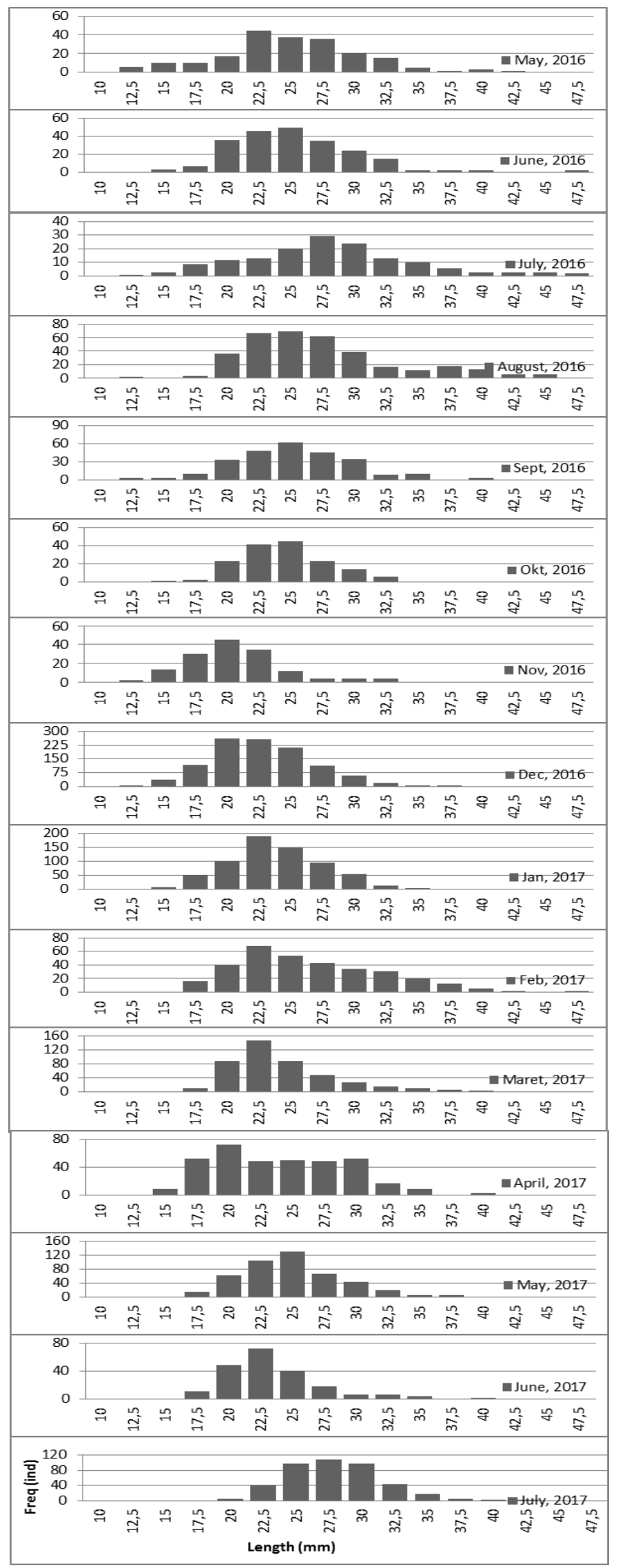

Figure 2. Size structure of $P$. merguiensis during the study (base on length) 


\section{Carapace length of the first-caught ( $C L_{c 50}$ )}

Carapace length of the first-caught of male $P$. merguiensis was $20.63 \mathrm{~mm}$, while female shrimp was $18.23 \mathrm{~mm}$ (Figure 4.). The gears used to catch $P$. merguiensis shrimp were minitrawl/arad, dogol, and sodo. The mesh size of net comprised 0.75 inch.

\section{Carapace length-weight relationship and condition factors}

The calculation on the length-weight relationship of $P$. merguiensis shows that male shrimp and female shrimp are negative allometry $(b<3)$. The equations of the shrimp length and weight during research are (Figure 4.):

Male shrimp: $\mathrm{W}=0.004 \times \mathrm{CL}^{2.32}$;
Female shrimp: $\mathrm{W}=0.0027 \times \mathrm{CL}^{2.44}$.

Condition factor of male shrimp was 1.1 while female shrimp was 1.3. It means that female shrimp has bigger size than male shrimp.

\section{Growth parameters}

The growth of female $P$. merguiensis was faster compared to male shrimp. It can be seen from the value of $\mathrm{K}$ (index of growth curve) of female shrimp (1.2) having $\mathrm{CL}_{\infty}=57.25 \mathrm{~mm}$ was bigger than male shrimp having $\mathrm{K}=1.3$ and $\mathrm{CL}_{\infty}=52.5 \mathrm{~mm}$. The growth of male $P$. merguiensis was based on the equation $\mathrm{CL}_{\mathrm{t}}=52.5\left(1-\mathrm{e}^{-0.41(\mathrm{t}+0.103072)}\right)$, while female $P$. merguiensis was based on $\mathrm{CL}_{t}=57.25$ (1-e $0,69(t+0.109102))$. Von Bertalanffy growth curve for $P$. merguiensis is presented in Figure 5.

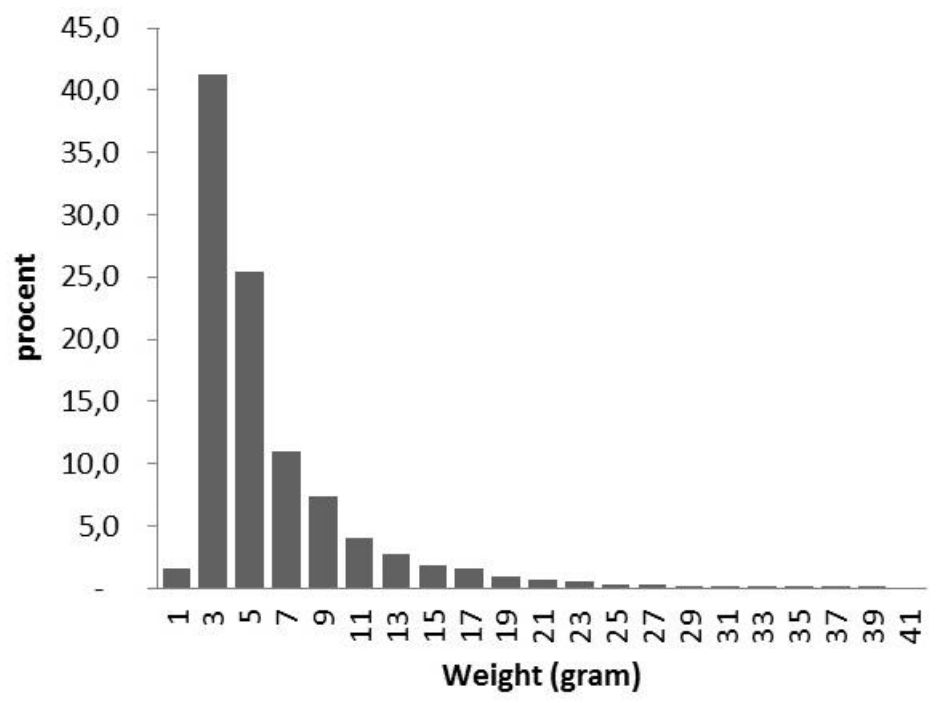

Figure 3. Size structure of $P$. merguiensis during the study (based on weight)

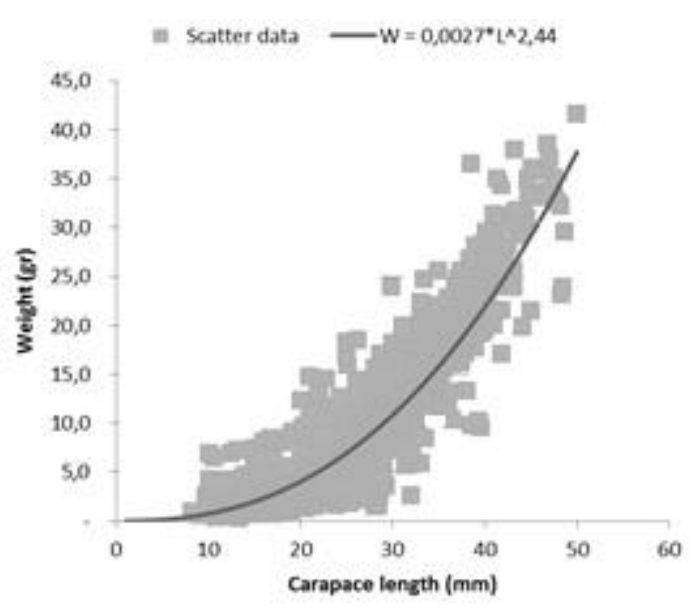

(a)

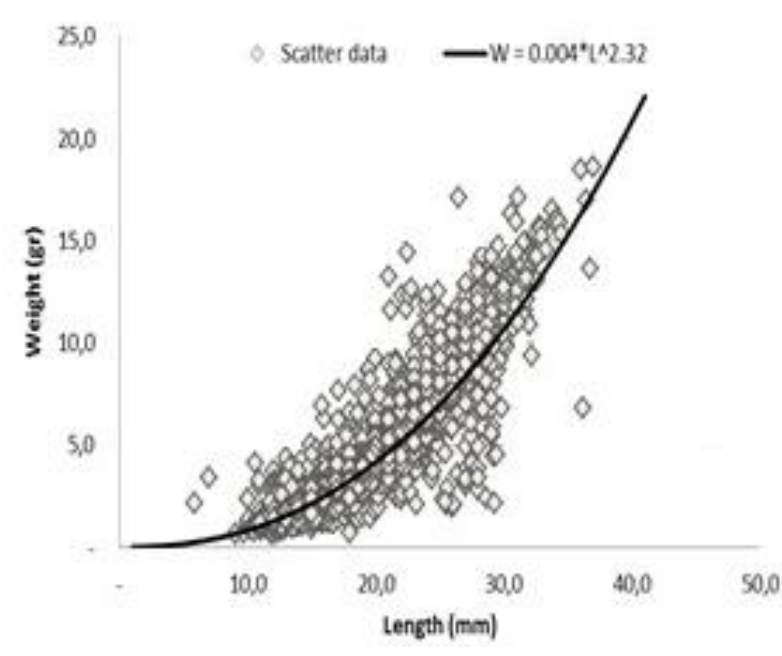

(b)

Figure 4. Length-weight relationship of shrimp P. merguiensis female $(A)$ and male $(B)$ the northern coastal waters of Western Central Java 


\section{Recruitment pattern}

The recruitment occurs the whole year, and recruitment peak is in April and August for female shrimps, and in March and August for male shrimp. Figure 6. The size of carapace length during recruitment is $20-20.5 \mathrm{~mm}$.

\section{Mortality and exploitation rate}

Total mortality rate $(Z)$ represents fishing mortality (F) and natural mortality (M). For male $P$ merguiensis, the value of $\mathrm{Z}$ was $4.51 \mathrm{y}^{-1}, \mathrm{M}=1.86 \mathrm{y}^{-1}$, and $F=2.65 \mathrm{y}^{-1}$ (Figure 8.). The exploitation rate $(\mathrm{E}=\mathrm{F} / \mathrm{Z})$ was 0.59 . While for female $P$ merguiensis, the value of $Z=5.36 \mathrm{y}^{-1} ; M=1.72 \mathrm{y}^{-1}, F=3.64 \mathrm{y}^{-1}$ and $\mathrm{E}=0.68$. It means that the exploitation of female $P$. merguiensis has exceeded the optimum level or overfishing. The facts also suggest that female shrimp has exploited more than male shrimp.

Length-weight relationship of $P$. merguiensis in the Western of the northern coastal water of Central Java is negative allometry, for both male and female shrimp. Female shrimp has bigger size compared to male shrimp, based on female shrimp condition factor 1.3, fatter or more plump than male shrimp (Condition Factor=1.1). Tirtadanu and Ernawati (2016) in northern coastal water of Pemalang Regency, Central Java also obtained negative allometry pattern for both male and female shrimp. Suryanti et al. (2018) obtained negative allometry for male shrimp and positive allometry for the female pattern when conducting length-weight relationship of $P$. merguiensis in mangrove ecosystem, North Sumatera.

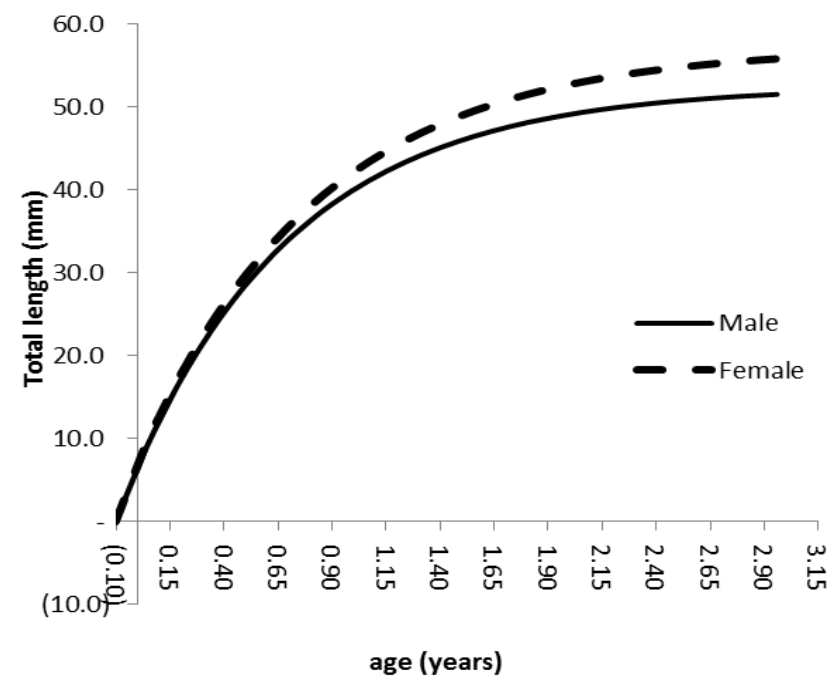

Figure 5. Shrimp growth curve of $P$. merguiensis shrimp in the northern coastal waters of Western Central Java
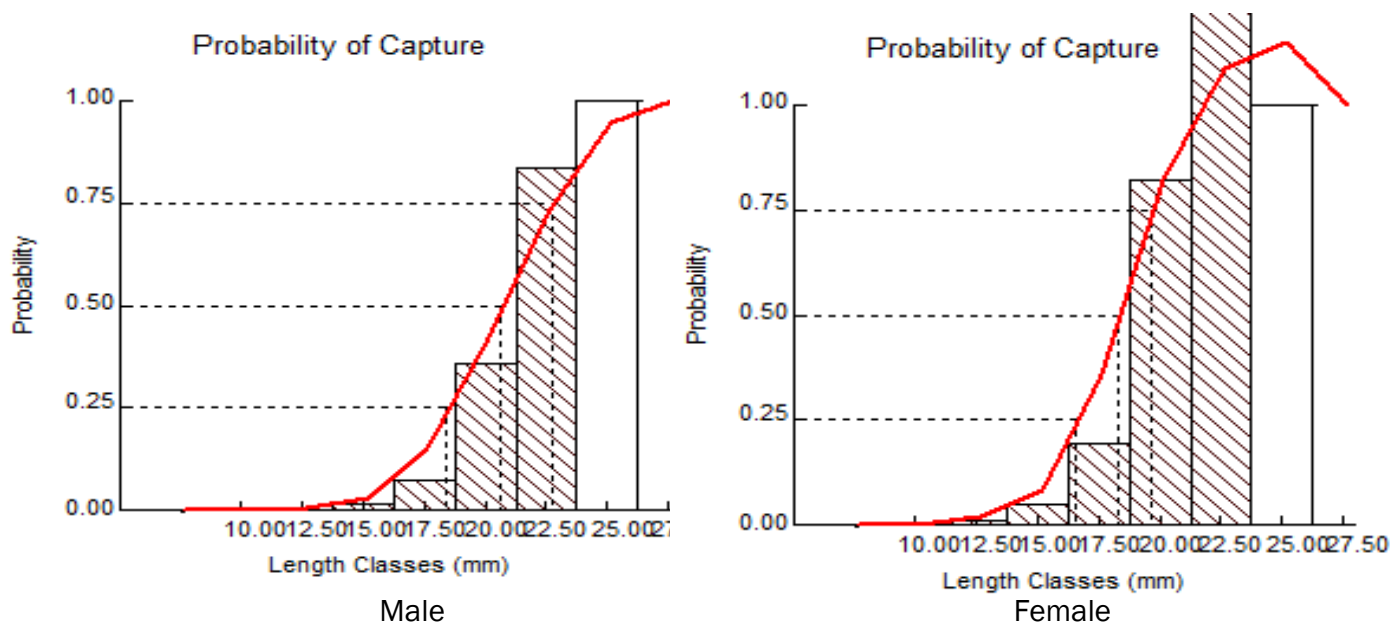

Figure 6. The carapace length curve was first caught $P$. merguiensis shrimp female and male 


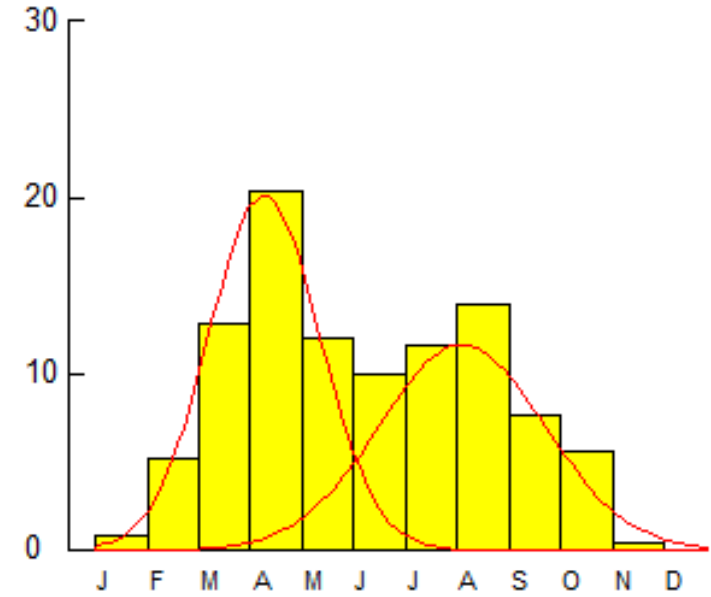

(a)

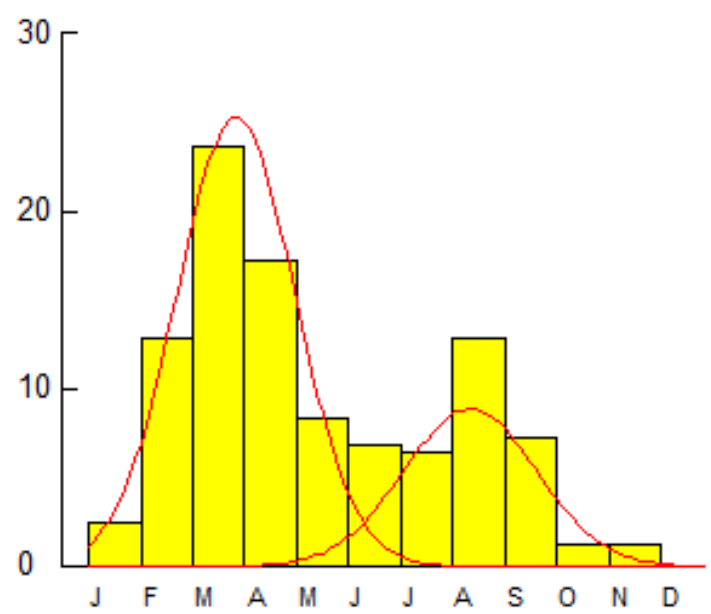

(b)

Figure 7. Pattern recruitment of $P$. merguiensis shrimp on the western part of the northern coastal waters of Western Central Java (females:A and males:B)

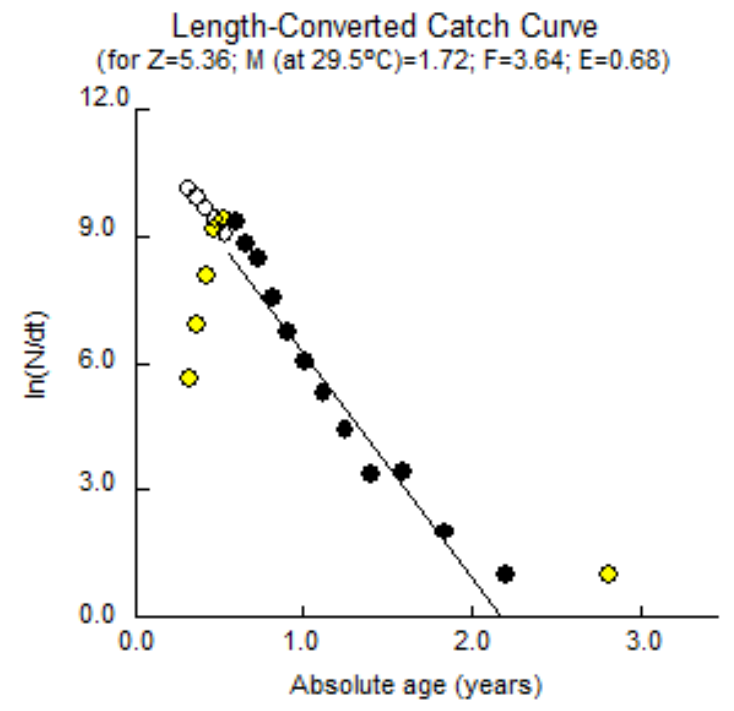

(a)

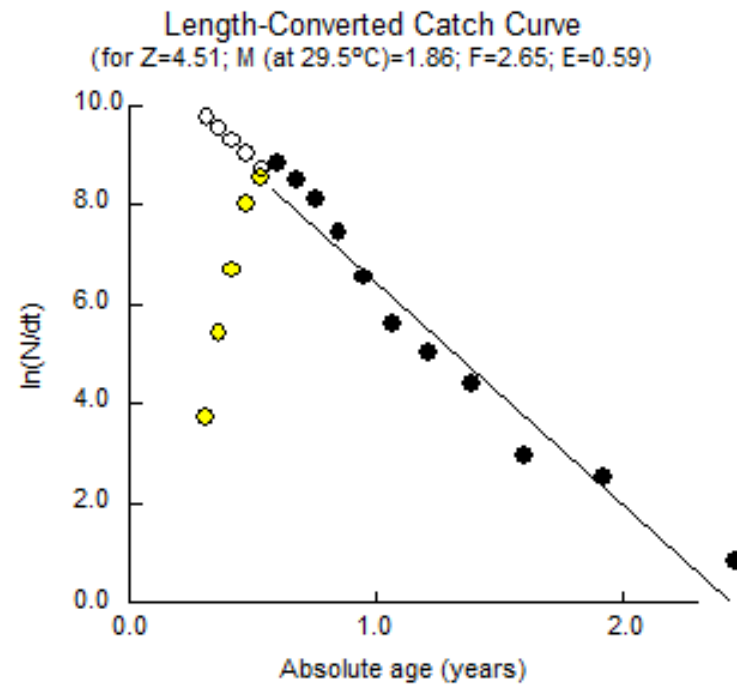

(b)

Figure 8. Curve of mortality rate of Female (A) and female (B) P.merguiensis shrimp in the northern waters of western Central Java.

The size of shrimp during recruit using Minitrawler, Danish seine, and sodo was 20$22.5 \mathrm{~mm}$, weighing $2-4 \mathrm{~g}$. The first-catch carapace length of male $P$. merguiensis was $20.9 \mathrm{~mm}$, while for female $19.6 \mathrm{~mm}$. Saputra (2007) in Segara Anakan Laguna, Cilacap using Apong obtained value of $\mathrm{CL}_{\mathrm{c} 50 \%}=18 \mathrm{~mm}$. Kembaren and Suman (2013) in Tarakan waters, East Kalimantan using minitrawls obtained $C_{c 50 \%}=35 \mathrm{~mm}$ and $L_{m 50}=33.86 \mathrm{~mm}$. Tirtadanu and Ernawati (2016) in Pemalang Regency waters using trammel net and arad obtained $\mathrm{CL}_{\mathrm{c} 50 \%}$ $=29.4 \mathrm{~mm}$ and $\mathrm{Lm}_{\mathrm{m} 50}=42,85 \mathrm{~mm}$. Nurdin and Kembaren (2015) in Sampit waters, Central Kalimantan using trammel net gear and Danish seine obtained $\mathrm{CL}_{\mathrm{c50}}=30.05 \mathrm{~mm}$ and $\mathrm{L}_{\mathrm{m} 50}=$ $39.4 \mathrm{~mm}$. Based on the data presented, it is obvious that the size of caught shrimp using arad, sodo, and Danish seine was relatively small $(19.9 \mathrm{~mm}$ and $20.9 \mathrm{~mm}$ ) and far below $L_{M 50}$. The condition is a serious threat to the sustainability of $P$. merguiensis in the coastal waters because of the availability of shrimp broodstock.

Von Bertalanffy growth parameter of $P$. merguiensis obtained were $\mathrm{CL}_{\infty}=57.25 \mathrm{~mm}, \mathrm{~K}=1.2$ $\mathrm{y}^{-1}$ (female) and $\mathrm{CL}_{\infty}=52.5 \mathrm{~mm}, \mathrm{~K}=1.3 \mathrm{y}^{-1}$ (male). Nurdin and Kembaren (2015) in Sampit, Central Kalimantan using trammel net and Danish seine 
obtained found the value of $\mathrm{CL}_{\infty}=57.8 \mathrm{~mm}$ and $\mathrm{K}=1.45 \mathrm{y}^{-1}$. Safaie $(2015)$ in northern coastal waters of Persian Gulf, Iran, obtained the value of $\mathrm{CL}_{\infty}=$ $48 \mathrm{~mm}, \mathrm{~K}=1.6 \mathrm{y}^{-1}$ for male and $\mathrm{CL}_{\infty}=54 \mathrm{~mm}, \mathrm{~K}=1.8$ $\mathrm{y}^{-1}$ for female. Momeni et al. (2016) researched Strait of Hormoz, the Persian Gulf using bottom trawl and obtained the value of $\mathrm{CL}_{\infty}=39.5 \mathrm{~mm}, \mathrm{~K}=1.8$ (male) and $\mathrm{CL}_{\infty}=50 \mathrm{~mm}, \mathrm{~K}=1.5 \mathrm{y}^{-1}$ (female). Kembaren and Suman (2013), based on mini trawl catch in Tarakan waters, North Kalimantan, obtained $\mathrm{CL}_{\infty}$ P.merguiensis $80 \mathrm{~mm}$, with $\mathrm{K}=1.45 \mathrm{y}^{-1}$. Bhadra and Biradar (2000) in their length-based study in Mumbai coastal waters obtained $\mathrm{L}_{\infty}=220 \mathrm{~mm}$, with $\mathrm{K}=1.8 \mathrm{y}^{-1}$ (male) and $\mathrm{CL}_{\infty}=281 \mathrm{~mm}$ with $\mathrm{K}=1.7 \mathrm{y}^{-1}$ (female). Mane and Deshmukh (2011) in their study in Maharashtra India obtained $\mathrm{L}_{\infty}=203.7 \mathrm{~mm}$ with $\mathrm{K}=2.15 \mathrm{y}^{-1}$ (male) and $\mathrm{L}_{\infty}=254.9 \mathrm{~mm}$ with $\mathrm{K}=1.9 \mathrm{y}^{-1}$ (female).

The value of $L_{\infty}$ depends on gear selectivity and fishing ground. The operational area of Minitrawl, Danish seine, and sodo is coastal water, thus having a small value of $\mathrm{L}_{\infty}$. Trawl, with its low selectivity and operated offshore, has bigger $L_{\infty}$ value. Next, trammel net is more selective and operated offshore. Thus the value of $L_{\infty}$ is bigger

The value of $\mathrm{K}$ is curve parameter showing the speed of fish in obtaining its maximum value $\left(L_{\infty}\right)$. The bigger $K$ value shows a faster growth of shrimp. It indicates that the growth of $P$. merguiensis in northern coastal water of Central Java is slower compared to others based on the result of various studies.

Based on analysis on recruitment pattern, $P$. merguiensis has double recruitment pattern, and the peak occurs in April and August (female), and March and August (male). In Tarakan coastal waters, the peak of $P$. merguiensis recruitment occurs in May (Kembaren and Suman, 2013). Momeni et al. (2016) reported that $P$. merguiensis in Strait of Hormoz, Persian Gulf, has whole year recruitment pattern and peaks from July to November.

Estimated total mortality rate $(\mathrm{Z})$, natural mortality rate $(\mathrm{M})$, fishing mortality rate $(\mathrm{F})$ and exploitation rate $(\mathrm{E})$ of male Penaeus merguiensis in the western part of northern coastal waters of Central Java were $Z=4.51 \mathrm{y}^{-1} ; M=1.86 \mathrm{y}^{-1}, \mathrm{~F}=2.65 \mathrm{y}^{-1}$ and $E(F / Z)=0.59$. While the estimated rate for female shrimp was $Z=5.36 \mathrm{y}^{-1}, \mathrm{M}=1.72 \mathrm{y}^{-1}, \mathrm{~F}=3.64$ $\mathrm{y}^{-1}$, and $\mathrm{E}=0.68$. Compared to other studies, the mortality rate is relatively lower. The mortality rate of $P$. merguiensis in Segara Anakan waters, Cilacap, Central Java, were bigger and recorded as $Z=7.02 \mathrm{y}$ $1, \mathrm{M}=1,96 \mathrm{y}^{-1}, \mathrm{~F}=5.06 \mathrm{y}^{-1}$ and $\mathrm{E}=0.72$ (Saputra and Subiyanto, 2007). Kembaren and Suman (2013) in the research in Tarakan waters, East Kalimantan, obtained not different value $\mathrm{Z}=4.85 \mathrm{y}^{-1}, \mathrm{M}=1.76 \mathrm{y}^{-1}$,
$\mathrm{F}=3.09 \mathrm{y}^{-1}$, and $\mathrm{E}=0.64$. Nurdin and Kembaren (2015) in Sampit waters, Central Kalimantan, also obtained not different $Z$, recorded as $5.7 \mathrm{y}^{-1}, \mathrm{M}=$ $1.93 y^{-1}, F=3.77 y^{-1}$, and $E=0.66$. Syafaei (2015) for his research in the Persian Gulf obtained $Z=8.27 \mathrm{y}^{-1}$, $M=2.1 y^{-1}, F=6.17 y^{-1}$, and $E=0.87$ for male shrimp and $\mathrm{Z}=6.97 \mathrm{y}^{-1}, \mathrm{M}=2.19 \mathrm{y}^{-1}, \mathrm{~F}=4.78 \mathrm{y}^{-1}$ and $\mathrm{E}=$ 0.69 for female shrimp. Bhadra and Biradar (2000) in Mumbai coastal waters obtained the values of $Z=9.79 y^{-1}, M=2.8 y^{-1}, F=6.99 y^{-1}$ and $E=0.7$ (male). While for female shrimp, the value of $Z=7.44 \mathrm{y}^{-1}$, $\mathrm{M}=2.6 \mathrm{y}^{-1}, \mathrm{~F}=4.84 \mathrm{y}^{-1}$ and $\mathrm{E}=0.65$ (female). Momeni et al. (2016) in Strait of Hormuz, Persian Gulf obtained the values of $Z=5.9 y^{-1}, M=2.9 y^{-1}, F=3.0 y^{-1}$ and $E=0.51$ (male) and $Z=5.7 y^{-1}, M=2.5 y^{-1}, F=3.2 y^{-1}$ and $E=0.56$ (female). The total mortality rate of $P$. merguiensis in the western of northern coastal waters of Central Java is relatively lower than other waters. The natural mortality rate is similar to the other waters in Indonesia, yet lower than Iranian water. The most influencing factor towards $M$ is the temperature of waters. Based on the explanation, it is obvious that the level of total mortality rate is influenced by the level of Fishing Mortality (F). Thus, the exploitation rate $(\mathrm{E})$ of $P$. merguiensis has exceeded the optimum level (0.50).

\section{Conclusion}

The length-weight relationship of $P$. merguiensis is a negative allometric. The growth rate of $P$. merguiensis in the northern coast waters of Central Java was found relatively low, the value of $K$ ranges from 1.2 to $1.3 \mathrm{y}^{-1}$. The total mortality rate $(Z)$ of shrimp $P$. merguiensis was quite high, $Z$ ranges from 4.51-5.36 $\mathrm{y}^{-1}$. The rate of exploitation (E) of shrimp $P$. merguiensis has exceeded the optimum limit, $\mathrm{E}$ ranges from 0.54 to 0.63 or has been overexploited.

\section{Acknowledgment}

We are grateful for funding supported by a grant from PNBP Diponegoro University under Research and Community Service Institute, scheme No: SP DIPA - 042.01.2.400898/2016 and No. DIPA-278-21/UN7.5.1/PG/2017.

\section{References}

Bauer, R.T. 2011. Amphidromy And Migrations Of Freshwater Shrimps. I. Costs, Benefits, evolutionary origins, and an unusual case of amphidromy. In New frontiers in crustacean biology (pp. 145-156). Brill. 
Bhadra, S. \& Biradar, R.S. 2000. Population Dynamics of Penaeid Prawn Penaeus merguiensis off Mumbai Coast. J. Indian Fish. Assoc. 27: 65-77.

Croccos, D.J. \& Kerr, J.D. 1983. Maturation and spawning of the banana prawn Penaeus merguensis de Man (Crustacea: Penaeidae) in the Gulf of Carpentaria, Australia. J. Exp. Mar. Biol. Eco. 69(1): 37-59. doi: 10.1016/0022-09 81(83)90171-5

Kembaren, D.D. \& Suman, A. 2013. Biology and Population Dynamics of Banana Shrimp (Penaeus merguiensis) In The Tarakan Waters, East Borneo. Ind. Fish. Res. J. 19(2): 99-105. doi: 10.15578/ifrj.19.2.2013.99-105.

Mane, S. \& Deshmukh, V.D. 2011. Age and growth studies of banana prawn, Penaeus merguiensis de Man from Maharashtra waters. J. Mar. Biol. Ass. India, 53(2): 184-188. doi: 10.6024/ jmbai.2011.53.2.01587-05.

Momeni. M. Kamrani. E., Safaie, M. \& Kaymaram, F. 2016. Population structure of banana shrimp, Penaeus merguiensis De Man, 1888 in the Strait of Hormoz, Persian Gulf. Iran. J. Fish. Sci. 17: 47-66. doi: 10.22092/IJFS.2018.115 584.

Nurdin, E. \& Kembaren, D.D. 2015. Population Parameters of White Shrimp (Penaeus Merguiensis) In Sampit And Adjacent Waters, Central Kalimantan. BAWAL Widya Riset Perikanan Tangkap. 7(2):103-109.

Pauly, D. 1983. Length-converted catch curves: A powerful tool for fisheries research in the tropics (part 1). Fish-byte. 1(2): 9-14.

Safaie, M., 2015. Population dynamics for banana prawns, Penaeus merguiensis de Man, 1888 in coastal waters off the northern part of the Persian Gulf, Iran. Tropical zoology, 28(1): 9-22. doi: 10.1080/03946975.2015.1006459

Saputra, S.W. \& Subiyanto. 2007. Analisis Stok Udang Jerbung (Penaeus merguiensis De Man)
Menggunakam Model Hasil Relatif per Rekruit $\left(Y^{\prime} / R\right)$ di Laguna Segara Anakan Cilacap. Prosiding Seminar Nasional Perikanan dan Kelautan: "Pengembangan IPTEK Perikanan dan Kelautan berkelanjutan dalam Mendukung Pembangunan Nasional" Fakultas Perikanan dan IImu Kelautan Universitas Diponegoro, 28 Agustus 2007. MSP\& IK:1-10.

Saputra, W.S., Solichin, A. \& Taufani, W.T. 2018. Stock Analysis of Metapenaeus affinis (H.Milne Edwards, 1837) on the North Coast of Central Java, Indonesia 3rd International Conference on Tropical and Coastal Region Eco Development 2017 IOP Publishing. IOP Conf. Series: Earth and Environmental Science 116: 012004 doi: 10.1088/1755-1315/116/1/01 2004.

Sheaves, M, Johnston, R., Connolly, RM. Baker, R. 2012. Importance of estuarine mangroves to juvenile banana prawns. Estuarine, Coast. Shelf Sci. 114: 208-219. doi: 10.1016/j.ecss.2012. 09.018

Siregar, G.A., Yunasfi, \& Suryanti, A. 2014. The Growth and Exploitation Rates of Kelong Shrimp (Penaeus merguiensis) in Langkat District, North Sumatera. J. Aquacoastmarine 4(3).

Sparre, P. \& Venema, S.C. 1999, Introduction to Tropical Fish Stock Assessment Part I. FAO Fisheries Technical Paper No. 306/1. Rev.2.

Suryanti, A., Riza, N. \& Raza'l, T.S. 2018. Lengthweight relationship and condition factor of white shrimp Penaeus merguiensis captured in ecosystem mangrove of Bagan Asahan, Tanjungbalai, Asahan, North Sumatra, Indonesia. IOP Conference Series: Earth and Environmental Science

Tirtadanu \& Ernawati, T. 2016. Biological aspects of banana prawn (Penaeus merguiensis de Man, 1888 ) in north coast of Central Java. BAWAL. 8(2): 109-116. 